DOI 10.18551/rjoas.2021-10.20

\title{
DISRUPTIVE TENDENCY OF SOCIAL MEDIA IN FAMILY SOCIAL INTERACTION AMONG WOMEN IN BORGU LOCAL GOVERNMENT AREA, NIGER STATE, NIGERIA
}

\author{
Ifejika L.I.* \\ Department of Home and Rural Economics, Federal College of Freshwater \\ Fisheries Technology, Nigeria \\ Igba C.E. \\ Department of Home Economics, Ebonyi State University, Nigeria \\ Ifejika P.I. \\ Socio-Economics and Extension Services, National Institute for Freshwater \\ Fisheries Research, Nigeria \\ Ozioko P.C. \\ Department of Home and Rural Economics, Federal College of Agriculture, Nigeria \\ Umunna M.O., ORCID: 0000-0002-5091-1895 \\ Federal College of Wildlife Management, Nigeria \\ *E-mail: lilianifejika@gmail.com
}

\begin{abstract}
Modern communication technologies have created new information behaviour which is obstructing the conventional pattern of family social relationship and interaction, hence the study on uniting and disruptive tendency of social media in family social interaction among women. The survey study was carried out among 120 respondents' to generate primary data through semi structured questionnaire and analyzed with percentage, mean and standard deviation. Findings showed that social media possessed both tendencies of uniting and disrupting conventional family social relationship and interaction due to new adopted lifestyle of women on mobile phone internet communication with social media platforms of WhatsApp $(\bar{x}=4.66)$, Facebook $(\bar{x}=4.52)$, YouTube $(\bar{x}=4.13)$ and Twitter $(\bar{x}=4.08)$. Social media enabled families to socially interact to express needs $(\bar{x}=4.85)$, family harmony $(\bar{x}=4.76)$, religious issues $(\bar{x}=4.74)$, resolving of family challenges $(\bar{x}=4.73)$, socialization $(\bar{x}=4.70)$ and health issues $(\bar{x}=4.70)$. Benefits of social media in uniting family relationship were to stay connected with members $(\bar{x}=4.82)$, quick passage of message $(\bar{x}=4.79)$, family bond $(\bar{x}=4.60)$, coordinate children activities $(\bar{x}=4.59)$ and cheap cost of communication $(\bar{x}=4.56)$. Observed disruptive tendencies of social media were distraction on face to face parenting, low quality time, creating depression, obstructing value, emerging internet addiction syndrome and less physical contact with family members. Prevailing evidences suggested moderation on usage to gainfully harness social media potentials as a uniting technology. Hence, women need sensitization, awareness creation and training to curtail excessive and abnormal disruptive tendencies of social media that are harmful to family relationship and interaction.
\end{abstract}

\section{KEY WORDS}

ICT, social media, social interaction, relationship, communication, family.

Globally, Information and Communication Technology (ICT) has altered the world view of communication with emergence of online tools like internet leading to new information behaviour. Access to internet network is responsible for the rising new lifestyle on ICT using social media platforms. In fourth quarter of 2020, Nigeria had 154,301,195 subscribers active on the internet while Niger State recorded 4,880,279 (3.16\%) active internet users through mobile (GSM) in all networks (Nigeria Bureau of Statistics, 2021). The adoption of social 
media as a new communication tool in lifestyle has altered the way family members communicate and interact. In our society now, social media is one of the fastest electronic platforms of spreading breaking news and trending events viral to individuals, groups, community and the globe. According to Chen and Zhang (2010), the compression of time and space, due to the convergence of new media and globalisation, has shrunk the world into a much smaller interactive field. This new communication style occurs through the use of inter-based tools like social media and smartphone devices like android which facilitates interaction among people to create, share or exchange information and ideas (Govenderet al., 2013).

Scott (2009) defined social media as a tool that provides a way people share ideas, content, thoughts, and relationships online. Also, Andres and Woodard (2013) view social media as internet-based tools for sharing and discussing information among people. Social media content is embedded on user-generated information, opinion, video, audio, and multimedia that is shared and discussed over digital networks. These new masses getting online are primarily by mobile device, especially where home-based communications infrastructure is relatively rare like Nigeria.

However, social media has brought changes to our family structure and cultural values. "Internet of Thing" is one the disruptive digital technologies reshaping the $21^{\text {st }}$ century families. Santraet al., (2019) consider social media as 'disruptive' in that it challenges and modifies the existing norms, institutional behaviours, and practices of society. Social media sites (Facebook, Twitters, WhatsApp, Instagram, YouTube and others) are popular and family members especially the youths go crazy of it. ICT devices of smartphone enable family members to communicate with images, voice, text, video, signs, to express divergent views and opinions. The use of social media has become a trend; users give importance to their Facebook friends and community more than their family members. In fact, the word, "family comes first" is losing its meaning to ardent social media users like Facebook, WhatsApp, Twitter, Instagram, YouTube video among others.

In a study on "How sociable women are on Social Media", Oyesomiet al., (2014) found that Nigeria women use social media to a high extent for various purposes like entertainment, socialization, information, network professionally, education, and empowerment. According to (comScore, 2012) on average, women spend more time online per month, 24.8 hours compared to 22.9 hours for men. But, when it comes to the social web, there is an even bigger divide between the genders. "Nearly $56 \%$ t of adult women say they use the Internet to stay in touch with people, compared to $46 \%$ of adult men," AnteContreras (2016) found that excessive use of social media has also shown to have effects on parenting; causing parental distraction, decreasing the level of everyday parental engagement, and making a child more likely to be at risk of injury. This is an eye opener on the disruptive tendency of social media on family and parenting due to new media lifestyle on internet. Perrin (2015) referencing Pew Research Center, stated that the internet is a common place utility in most homes now, with over $65 \%$ of adults using social media in some form. According to Kamga (2020), examination of disruptive studies is greatly useful to identify what habits are actually fading away due to social media and what new ones are being introduced and institutionalized. This is necessary since disruptive technologies supersede "an older process, product, or habit. These are evidences that social media has dual tendency of uniting and disrupting family norm on relationship and social interaction.

The family is therefore, being slowly replaced by other agents of socialization especially social media. Parents are losing the grip on value inculcation in children (Kembe, 2010). Study by Moody (2001) found that there is reduction and displacement of social activities in the family for the reason that the individuals like to spend much time online and they are not able to take part in face to face social activities. There is a decline in traditional nuclear family households as family members have become "more individualistic" and families are spending "less and less time together. Ifejika (2016) found among women an emerging new lifestyle with ICT and declining quality time with children in Borgu council area, Niger state, Nigeria. Thus, family's position in society has changed, and so traditional family values and the family itself have been eroded. Along with the rise of individualism and the 
decline in family values, Social media technologies are now much more immersed into family's daily routines than ever before. Digitalization has reduced the face to face interaction of family members and mobile phone has created a social situation whereby family members are getting used to avoidance of person to person communication by switching over to mobile. Alteration in family relationships, social interaction, alongside the rise of individualization linked to usage of social media technologies make this research very important. Therefore the general objective of the study is to investigate on uniting and disruptive tendency of social media in family social interaction among women in Borgu Local Government Area (LGA), Niger State.

The derived objectives are three fold: identify ICT devices used for communication; ascertain frequency of interaction with social media; describe benefits and negative effects of social media interaction on family relationship.

\section{METHODS OF RESEARCH}

Borgu council is one of the twenty five (25) local government areas that make up Niger State in North Central Geo-political Zone of Nigeria. Borgu Local Government Area lies between Latitude $90^{\circ} \mathrm{N}$ and $11^{\circ} \mathrm{N}$ and Longitude $2^{\circ} \mathrm{E}$ and $4 \mathrm{E}^{\circ}$. The Local Government has an area of land of about 16,200sqkm and shares boundaries with Benin Republic to the West, Agwara Local Government to the South, River Niger or Lake Kainji to the East. Borgu LGA in 2006 census has a population figure of 171,965 whereas women account for 83,612 $(48.6 \%)$. New Bussa is the headquarters of Borgu LGA and the only urban town with most modern infrastructure for socio-economic growth and development such as telecommunication networks of four (4) providers, hospitals, three academic institutions, post office, five financial institutions, military base, hotels, correctional homes, national park for tourism and wildlife conservation, popular Kainji dam for electricity generation and the lake for fishing among others. Women play important role in the family wellbeing and socioeconomic growth of the area with multiple roles in health, education, agriculture, small scale enterprises, reproduction, religion and socio-cultural activities.

Multistage sampling techniques were used to draw the sample. First step was stratification of the Borgu L.G.A into urban and rural areas along the existing ten (10) political wards; Waterside, Karabonde, Konkoso, Bussa, Malale, Dugga, Babanna, Pissa/Kabe, Shagunu and Wawa. Next step was purposive selection of New Bussa ward, as the only urban town and the headquarters of Borgu council area with strong telecommunication network and mixed society. Third step was stratification of New Bussa town into six areas namely Senior Camp, General Hospital Road, Ibadan Way Road, Benue Road, NIFFR Quarters, Marriage Quarter and Wawa garage for the study. Then, step four was proportional random selection of 20 women from the six strata to reflect entire urban town for the study. This gave 120 women as the sample size in the absence of any documented list of android mobile phone owners among women in the area. Instrument for data collection was semistructured questionnaire which was face validated by experts in the field. Information was elicited from respondents through face to face interview in July 2018 and data generated was analyzed with descriptive statistics including standard deviation, mean, percentages, and frequency. Five (5) points rating scale response was used as shown $(5+4+3+2+1 \div 4=$ $15 / 5=3.00$ ). Therefore, mean score $\geq 3.00$ was used as the criteria point for acceptance and mean score $\leq 3.00$ was criteria point for rejection.

\section{RESULTS AND DISCUSSION}

ICT Devices Used by Women for Communication with Family Members. Table 1 show that respondents (85.8\%) displayed high capability to use various mobile phone functions for communication with family members compared to laptop (41.7\%). Top on the mobile phone devices used for communication is voice call $(\bar{x}=4.81)$, followed by browsing $(\bar{x}=4.66)$, picture $(\overline{\mathrm{x}}=4.52)$, short message sending $(\overline{\mathrm{x}}=4.28)$, video $(\overline{\mathrm{x}}=4.13)$. This finding is an indication that most of the women used smartphone devices such as Blackberry, iPhone, and Android 
technologies, did internet browsing and had capability to share content online with images, video, voice recorded message and text messages. Ante-Contreras (2016) agreed with the finding that mobile phone is modern communication technology family members mostly use for social interaction. Emphasis should be to educate and train respondents to improve their skills on communicating with video, voice message recorder and images to derive more benefits.

Table 1 - ICT devices used by women for communication with family members

\begin{tabular}{llll}
\hline Variables & Mean $\overline{\mathrm{x}}$ & Standard deviation & Ranking \\
\hline Voice call & 4.81 & 0.56 & $1^{\text {st }}$ \\
Browsing & 4.66 & 0.91 & $2^{\text {nd }}$ \\
Picture & 4.52 & 0.94 & $3^{\text {rd }}$ \\
Short message sending & 4.28 & 1.21 & $4^{\text {th }}$ \\
Video & 4.13 & 1.39 & $5^{\text {th }}$ \\
Laptop & 2.10 & 1.98 & $6^{\text {th }}$ \\
\hline
\end{tabular}

Source: Field survey 2018 Bench mark: $\geq 3.00$ Accept, $\leq 3$ Reject.

Frequency of Using Social Media for Social Interaction with Family Members. Responses on Table 2 show the frequency of communicating through social media for social interactions with family members which was very high on daily usage (70-82 \%) but declined drastically from $2-3$ per week (10-15\%), weekly (5-7\%), fortnightly and monthly $(<5 \%)$. As revealed, respondents indicated high daily usage of four social media platforms thus; Facebook (82.5\%), WhatsApp (75.8\%), Twitter (70.8\%), YouTube (69.2\%). Prevailing evidence justifies that women under study are active social media users probably due to their adopted social lifestyle, acquisition of smartphones, access to network and ability to share content with text, images and video. Oyesomiet al., (2014) found $86 \%$ response on familiarity with social media while Facebook (49\%) and Twitter (43\%) among women in Nigeria. In agreement with the finding on active daily usage by women was research conducted by Ante-Contreras (2016) observed that $75 \%$ of parents described themselves as using social media devices upwards of three times a day. Also, Mauritzson and Sandberg (2004) supported this fact stating that the decrease in family time coincided with the growth of social networks usage. Active daily social media usage has implication on the displacement of "strong ties" among the family members. Turkle (2011) examined the effects of technology on family relationships among 300 young people and 150 adults and found that children were often times the ones complaining about their parents' obsession with technology. Turkle further discovered that many children believed their parents paid less attention to them than to their smart phone, often times neglecting to interact with them face-to-face until they had finished responding to messages. Interaction with picture and video are entertaining, appealing and more understandable to clarify issues and messages. Above findings are suggesting disruptive tendency of social media due to long hours spent on social media. In view of the prevailing circumstances, respondents need caution to be able to spend quality time with their family and avoid internet addiction syndrome.

Table 2 - Frequency of social media usage for social interaction with family members

\begin{tabular}{|c|c|c|c|c|c|}
\hline Variables & Daily & 2-3per week & Weekly & 2 weeks & Monthly \\
\hline Facebook & $99(82.5)$ & $13(10.8)$ & $7(5.8)$ & $0(0)$ & $1(0.8)$ \\
\hline WhatsApp & $91(75.8)$ & $18(15.0)$ & $8(6.7)$ & $2(1.7)$ & $1(0.8)$ \\
\hline YouTube & $83(69.2)$ & $18(15.0)$ & $9(7.5)$ & $6(5.0)$ & $4(3.3)$ \\
\hline Twitter & $85(70.8)$ & $15(12.5)$ & $9(7.5)$ & $5(4.2)$ & $6(5.0)$ \\
\hline
\end{tabular}

Source: Field survey 2018 Bench mark: $\geq 3.00$ Accept, $\leq 3$ reject.

Responses on Social Interaction Issues Discussed with Family Members. Table 3 relates to responses on nine issues respondents discussed with family members through social media with mean score above the bench mark of $(\bar{x}=\geq 3)$ for acceptance. From the results, critical issues on family agenda discussed by the women revolved around health, needs, connection, religion, challenges, harmony, jokes and security. Topmost social interaction with family members was expression of needs and concern $(\bar{x}=4.85)$, followed by 
stay connected with outside home $(\bar{x}=4.78)$, family harmony and security respectively $(\bar{x}=4.76)$, health issues $(\bar{x}=4.74)$, resolving of family challenges $(\bar{x}=4.73)$, and mentioned is jokes and comedy for socialization $(\bar{x}=4.70)$ and religion issues $(\bar{x}=4.70)$. Anyakoha (2015) asserted that extensive and intensive relationships exist among family members including the sharing of work, play, food, rest, joy, and crises together. Ante-Contreras (2016) also opined that most of the family members expressed their needs, want and concern to each other and gives moral encouragement. In addition, Ante-Contreras said that social interaction in the family helped members of the family to express their love and feelings for one another. Above findings buttress the fact that women under study used social media to maintain family bond through interaction, sharing and discussion of pertinent issues on social, health, security and religion. Probably, pertinent family issues might be responsible for high daily usage of social media for interaction among respondents.

Table 3 - Response on social interaction issues discussed with family members

\begin{tabular}{llll}
\hline Variables & Mean $\bar{x}$ & Standard deviation & Remarks \\
\hline Discussions on health issues & 4.74 & 0.59 & Accept \\
Family peace and harmony & 4.76 & 0.18 & Accept \\
Joke and comedy for socialization & 4.70 & 0.69 & Accept \\
Resolving of family challenges & 4.73 & 0.59 & Accept \\
Expression of needs \& concern & 4.85 & 0.48 & Accept \\
Religious issues & 4.70 & 0.69 & Accept \\
Stayed connected outside home & 4.78 & 0.48 & Accept \\
Give moral encouragement & 4.70 & 0.76 & Accept \\
Discussed issues of security in the society & 4.76 & 0.18 & Accept \\
\hline
\end{tabular}

Source: Field survey, 2018. Bench mark: >3 Accept, < 3 Reject.

Response on Benefits Derived from Social Media as a Uniting Technology with Family Members. Table 4 explains respondents' benefits derived from social media as a uniting technology for social interaction with family members. The finding is a justification that social media is digitally uniting families through interaction with family members on to be connected and stay together $(\bar{x}=4.82)$, quick sharing of messages $(\bar{x}=4.79)$, promote family bond and love $(\bar{x}=4.60)$, help parents moderate family activities $(\bar{x}=4.59)$, cheap cost of communication $(\bar{x}=4.56)$ and to be alert on security issues $(\bar{x}=4.42)$. The benefits establish that social media is one of the fastest ways of broadcasting and spreading breaking news or trending event among family members. Confirming the finding was Rideout et al., (2010) who said that social media had become an essential feature of the family social lives by making communication and social interactions more accessible to family members, strengthening and maintaining bonds with grandparents and other relatives who may live far away. To buttress this, Scott (2009) held that technology is sanctification to create communication and social interaction with our relatives and precious ones, and to strengthen our relationships with our friends, and families. It implies that women under study are deriving value from usage of social media for social interaction with family members necessitating their daily usage for communication.

Table 4 - Response on benefits derived from social media as a uniting technology for interaction in the family

\begin{tabular}{llll}
\hline Variables & Mean $\overline{\mathrm{x}}$ & Standard deviation & Remarks \\
\hline Be connect and stay together & 4.82 & 0.49 & Accept \\
Promotes family bond and love & 4.60 & 0.70 & Accept \\
Quick sharing of message & 4.79 & 0.47 & Accept \\
Cheap cost of communication & 4.56 & 0.73 & Accept \\
Help parents moderate family activities & 4.59 & 0.72 & Accept \\
Alert on security tips and issues in society & 4.42 & 0.76 & Accept \\
\hline
\end{tabular}

Source: Field survey, 2018. Bench mark: >3 Accept, < 3 Reject.

Response on the Disruptive Influence of Social Interaction on Family Interaction. Table 5 presents responses on the disruptive influences of social media interaction on family interaction and relationship. That six (6) disruptive tendencies identified is an indication that 
social media is distracting cordial relationship among family members. Foremost disruption observed was parents paid less attention to their children $(\bar{x}=4.77)$, followed by possibility of depression due to loneliness $(\bar{x}=4.70)$, emerging internet addiction syndrome $(\bar{x}=.4 .67)$, changed traditional value of socialization $(\bar{x}=4.66)$, less quality time together $(\bar{x}=4.65)$ and reduced face-to-face contact ( $\bar{x}=4.54)$. In agreement, Turkle (2011) noted that many children believed their parents paid less attention to them than to their smart phone, often times neglecting to interact with them face to face until they had finished responding to messages on their phone. Also, Rideout et al., (2010) confirm emerging internet addiction syndrome in the family both young and the old. They found children ages 8-18 spent over 7.5 hours a day, 7 days a week using media sites outside of school. Teenagers between the ages of 1217years reported using text messages in their daily lives more than any other form of communication, including face-to-face interaction (Lenhart et al., 2010). A large part of this generation's social and emotional development is occurring while on the internet and cell phones. It makes family members not to spend time together and it also affects traditional family values. Pew (2008) said that technology did not replace face-to-face interaction rather, it complemented it. Ifejika (2016) cautioned on the issue of women spending less quality time with children in the family due to new ICT lifestyle. Ante-Contreras (2016) reported that frequent eye contact, one on one time, and undivided attention were necessary in building a secure attachment between a parent and child. In this case, respondents need to moderate excessive usage of social media to avoid internet addiction, divided attention, less quality time and gap on relationship with family on face to face interaction.

Table 5 - Response on the disruptive influences of social media interaction on family members

\begin{tabular}{llll}
\hline Variables & Mean $\overline{\mathrm{x}}$ & Standard deviation & Remarks \\
\hline Reduced face-to-face contact & 4.54 & 0.78 & Accept \\
Changed traditional value of socialization & 4.66 & 0.63 & Accept \\
Parents paid less attention to their children & 4.77 & 0.51 & Accept \\
Spent less quality time with family & 4.64 & 0.60 & Accept \\
Possibility of depression due to loneliness & 4.70 & 0.66 & Accept \\
Emerging internet addiction syndrome & 4.67 & 0.60 & Accept \\
\hline
\end{tabular}

Source: 2018 field survey Bench mark: >3 Accept, < 3 Reject.

\section{CONCLUSION}

Evidence from the study demonstrated that women have capacity to use mobile phone functions to browse internet on social media platforms for social interaction and relationship with family members. Also, social media has both uniting and disruptive tendencies on family social interaction and relationship. Respondents used social media to discuss family issues revolving around heath, needs, connection, religion, challenges, harmony, jokes and security. Also, benefits derived in uniting families were being be connected and staying together, quick sharing of information, family bond, coordination, security alert and cheap communication. Observed disruptive tendencies identified include distracting cordial relationship on parenting, reduced face-to-face communication, less quality time, depression, making many parents pay less attention to their children, spending less time together, and changing traditional family structures and values. Way forward to solidify benefits of social media interaction include sensitization of women and family members on the inherent merits and demerits of social media on family interactions, to guide against addiction, address the issue of quality time, and appropriate utilization of social media to enhance the overall wellbeing of family members and the society at large.

\section{REFERENCES}

1. Andres, D and Woodard, J (2013).Social Media Handbook for Agricultural Development Practitioners.

2. Ante-Contreras, D. (2016). Distracted parenting: how social media affects parent-child attachment. Thesis, Degree Master of Social Work, Faculty of California State University. 
3. Anyakoha, E.U. (2015). Home management for schools and colleges, Ibadan: African Feb Publisher Limited. 101 - 103.

4. Chen, G. M., and Zhang, K. (2010). New media and cultural identity in the global society. In R. Taiwo (Ed.), Handbook of Research on Discourse Behavior and Digital Communication: Language Structures and Social Interaction (pp. 801-815). Hershey, PA: Idea Group Inc.

5. comScore (2012). 2012 Mobile Future in Focus. http://www.comscore.com.

6. Govender, K.K., Yavisha, R., and Krishna K. (2013).The Relationship among certain youths' demographic variables and their social media browsing behaviour. African Journal of Business Management 7(25) (2013): 2495-2499.

7. Ifejika, L.I (2016).Material lifestyle and its effect on adolescent behaviours in Borgu Local Government Area of Niger State, Nigeria. M.Sc. thesis, University of Agriculture, Markurdi, Benue State. 66p

8. Kamga, S. (2020). Social Media as Disruptive Technologies in an Era of Fake News: Examining the Efficacy of Social Media in the Shaping of the Political Landscape in Africa.DOI: 10.4018/978-1-7998-1791-8.ch010.https://www.researchgate.net/publicatio $\mathrm{n} / 339115706$.

9. Kembe, E. M. (2010). Socio-Cultural Practices influencing the Implication of Child's Right Act in Nigeria. Journal of Home Economics Research, 12: $25-32$.

10. Lenhart, A., Lenhart, A., Purcell, K., Smith, A., and Zickuh, K. (2010).Social media and mobile internet use among teens and young adults. https://www.researchgate.net.

11. Mauritzson-Sandberg, E., and Nordmark, T. (2004). ICT-the solution of communication hurdles in the modern family? Human Perspectives in the Internet Society: Culture, Psychology and Gender, 4, 135-141.

12. Moody, E. J (2001).Internet use and its, relationship to loneliness. Cyber psychology and behaviour, 4:393-401.

13. Oyesomi, K., Okorie, N., Omole, F., and Smith, A. (2014). How sociable are women on Social Media? An experiential study on Nigerian women. International Journal of Research in Social Sciences, 4:2.

14. Perrin, A. (2015). Social Media Usage: 2005-2015. Pew Research Center. Retrieved from: http://www.pewinternet.org/2015/10/08/social-networking-usage-2005-2015/.

15. Pew internet and American life project (2008). Traditional nuclear families use the internet and cell phones to create a "new connectedness" that revolves around remote interactions and shared online experiences http://www.pewinternet.org/2008/10/19/.

16. Rideout, V.J., Foehr, U.G0 and Roberts, D.F. (2010).Generation M2 Media in the Lives of 8- to 18-Year-Olds.A Kaiser Family Foundation Report. Retrieved July 30, 2010, from http://www.kff.org/entmedia/upload/8010.pdf.

17. Santra, S., Mandal, T. S., and Das, P. (2019). Leveraging Disruptive Technology Innovations for Healthcare Delivery in Sub-Saharan Africa, ORF Issue Brief No. 298.

18. Scott, D. M. (2009). The New Rules of Marketing and PR, How to Use Social Media, Blogs, News Releases, Online Video, \&Viral Marketing to Reach Buyers Directl. Hoboken, NJ: John Wiley \& Sons. p. 38.

19. Turkle, S. (2011). Alone Together: Why We Expect More from Technology and Less from each Other. Basic Books, Inc., New York, NY, USA. p. 241.ISBN 9780465010219. 